\begin{tabular}{l|c|c}
\hline ISSN: 0001-5113 & ACTA ADRIAT., & UDC: 639.64.(262.3)543.48 \\
AADRAY & 52(1): $21-28,2011$ & U \\
\hline
\end{tabular}

\title{
Spectral reflectance profile of Caulerpa racemosa var. cylindracea and Caulerpa taxifolia in the Adriatic Sea
}

\author{
Mak KIŠEVIĆ ${ }^{1 *}$, Amer SMAILBEGOVIĆ ${ }^{2}$, Kyle T. GRAY ${ }^{3}$, Roko ANDRIČEVIĆ ${ }^{1}$, \\ Jonathan D. CRAFT ${ }^{4}$, Vedran PETROV ${ }^{1}$, Dajana BRAJČIĆ ${ }^{1}$ and Ivana DRAGIČEVIĆ ${ }^{1}$ \\ ${ }^{1}$ Faculty of and Civil Engineering, Architecture and Geodesy, University of Split, Croatia \\ ${ }^{2}$ Photon d.o.o., Split, Croatia \\ ${ }^{3}$ Department of Geology and Environmental Geosciences, College of Charleston, SC, USA \\ ${ }^{4}$ Grice Marine Laboratory, College of Charleston, SC, USA \\ *Corresponding author, e-mail: mak.kisevic@gradst.hr
}

The invasive algae in the Mediterranean Caulerpa taxifolia and Caulerpa racemosa var. cylindracea have gained much interest in the Adriatic Sea due to their fast spread and negative impacts on native seaweed species. Lack of accurate mapping and its overall high costs represent some of the major difficulties for successful detection and subsequent environmental management. Remote sensing techniques could provide a quicker, more accurate and more cost efficient approach to mapping these invasive species. In order to allow for classification of remotely sensed data, we have collected and analyzed hyperspectral reflectance profiles of both invasive Caulerpa species in the Adriatic and the native Caulerpa cf. laetevirens species from the southeastern Atlantic coast of the United States. We have measured distinctive spectral features for spectroscopically distinguishing between these species, which is particularly interesting in the areas where these native and invasive species coexist. The initial results suggest that it might be possible to distinguish between the species based on their spectral reflectance profile. These results would have to be verified with samples taken from more populations in different phenological phases of the seaweed growth and other environmental conditions.

Key words: algae, optical properties, environmental monitoring, remote sensing

\section{INTRODUCTION}

Caulerpa taxifolia is natively found in the tropical seas where it grows in small patches and does not present major problems because it is kept in check by other competing species and herbivores (CARPENTER 1986, HAY 1997). Its presence in the Mediterranean was traced to tropical saltwater aquariums where it was used as a decorative plant and from where it started spreading into natural habitats. In 1984 the seaweed was discovered flourishing, for the first time in the Mediterranean, near the
Oceanographic Museum in Monaco (MEINESZ et al. 1993), and since then it has quickly colonized large areas in the Mediterranean Sea. Elsewhere in the world, it was discovered in 2000 off the coasts of California (USA) and New South Wales (Australia) raising concerns over its invasion similar to those in the Mediterranean Sea and the associated eradication costs (JOUSSON et al. 2000, SCHAFFELKE et al. 2002, SCHAFFELKE et al. 2007).

In the Croatian Adriatic Sea, Caulerpa taxifolia was first discovered in 1994 and since then it has been recorded at three locations (ŽULJEVIĆ et al. 2010). 
Caulerpa racemosa is often found in the tropical to warm-temperate regions. It was first discovered in Tunisia in 1926, probably as an immigrant-species from the Red Sea (PIAZZI et al. 2001). It was not noted to be a typical invader, until the new form started quickly spreading since 1990 when it was discovered in Libya (NIZAMUDDIN 1991). The new form was named Caulerpa racemosa var. cylindracea and it was identified to be of southwestern Australia genetic origin. (VERLAQUE et al. 2003).

This alga is one of the most invasive species in the Mediterranean Sea, spreading even faster than Caulerpa taxifolia, and causing major modifications to benthic communities and negative impacts on human activities (CECCHERELLI et al. 2001, PIAZZI et al. 2001). A recent meta-analysis suggests that invasive seaweeds reduce native seaweed abundance and diversity (THOMSEN et al. 2009). Due to imprecise records, no estimation of the total surface area affected in the Mediterranean Sea can be made (KLEIN et al. 2008).

The first discovery of Caulerpa racemosa var. cylindracea in Croatia was in 2000 (ŽULJEVIĆ et al. 2003) and since then it has been recorded at 43 locations (ŽULJEVIĆ et al. 2010).

There is compelling evidence that the secondary spreading of both invasive algal species has been caused by shipping activities (ballast waters, anchors, fishing nets or other structures) (VERLAQUE et al. 2003). Accurate mapping of these species in the Adriatic Sea is necessary to follow the expansion of the algae, assessing their environmental impacts and implementing environmental management measures.

Remote sensing techniques are being tested as a tool to provide a quicker, more accurate and more cost efficient approach to mapping the distribution of the Caulerpa spp., setting up current baselines and determining the minimum detection threshold of the species within the larger background. Recent improvements to the hyperspectal optical sensors from the aspects of improved optics, signal-to-noise-ratio, spectral and spatial bandwidth and resolution, high spectral and, in the case of airborne sensors, wide aerial coverage, allows for the effective discrimination and mapping of different benthic communities in the coastal zone. Thereby, by eliminating the need to extrapolate from a small-scale data set(s) obtained from in-situ measurements underwater, the overall assessment can be enhanced, expedited and extended over a wider operational area. The spectral reflectance profile of aquatic vegetation is a fundamental tool for mapping submerged vegetation using optical remote sensing. The particular reflectance profiles (spectral signatures) of vegetation species are used in the various classification algorithms with the acquired remotely sensed data (MALTESE et al. 2008). The analysis of spectral features of Caulerpa taxifolia and Caulerpa racemosa var. cylindracea, may yield the best set of wavelengths and corresponding imagingsensor bands to be used for distinguishing amongst seaweed species in remotely sensed data and establishing detection parameters and imaging requirements for successful detection in a coastal zone, where the spectral response of the surface can still yield a useful signal. It must be emphasized, however, that the main limitation of the imaging spectroscopy stems from the availability of a useful signal reflected from the surface, as the water, aerosol, scatter, glint and atmosphere can all negatively effect and significantly degrade the capabilities of a point or an aerial spectral imaging system.

\section{MATERIAL AND METHODS}

The data were acquired on the island of Hvar in the central Adriatic Sea $\left(43^{\circ} 08^{\prime} \mathrm{N} 16^{\circ} 44^{\prime} \mathrm{E}\right)$, Croatia, where earlier surveys by the Institute for Oceanography and Fisheries have detected or indicated the presence of both Caulerpa species (Fig. 1).

The samples of Caulerpa taxifolia and Caulerpa racemosa var. cylindracea were collected at the beginning of June, 2009. Caulerpa taxifolia samples were collected at 10 to 15 meters water depth in the harbor of Stari Grad (Old Town), the place where it was first recorded in the Adriatic Sea in 1994. The 

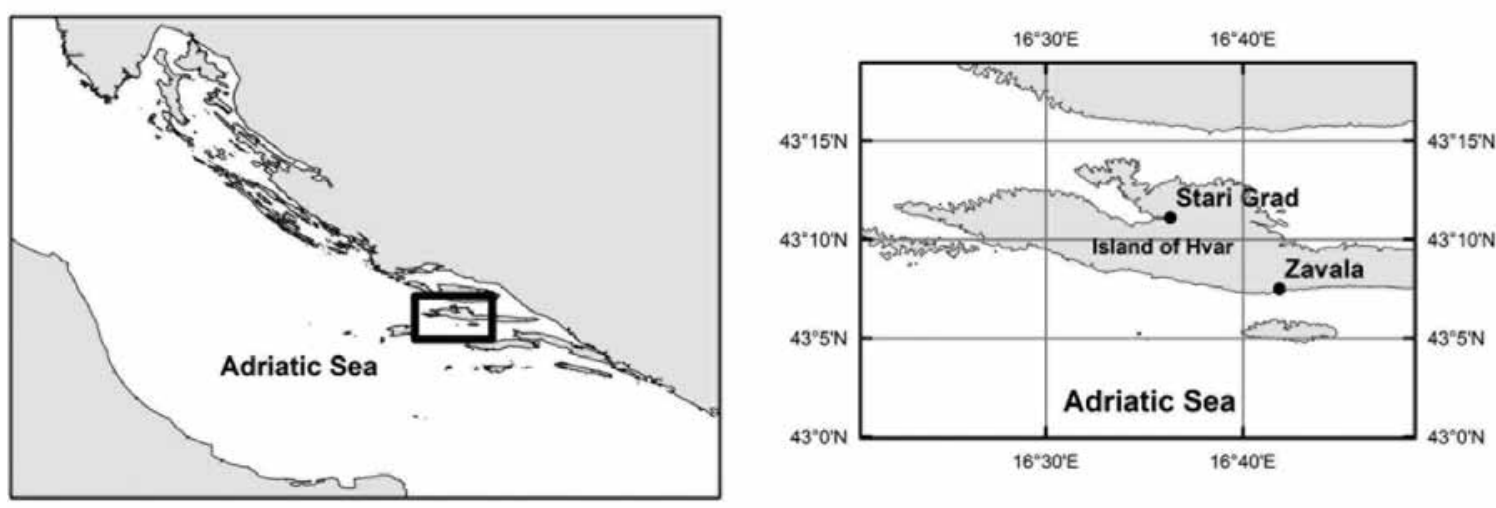

Fig. 1. The locations of the study area on the island of Hvar

harbor is located at the terminus point of the Stari Grad bay, which is approximately 14 $\mathrm{km}^{2}$ with measured depths varying from 0.2 to 25 meters. The bay is linked with the open sea by an opening to the north-west. In 1995 , the algae was spread over 6 hectares at the sampled location, and mapping carried out in 2005 showed its spread over an area of 70 ha (ŽULJEVIĆ et al. 2010).

The samples of Caulerpa racemosa var. cylindracea were collected near the settlement of Zavala at depths 5 to 10 meters. Zavala is located on the southern coastline of Hvar.

The specimen spectra were acquired in-air (with a thin film of sea water) and in-lab under artificial light to determine the overall characteristic reflectance spectra of each Caulerpa species. In-air images were collected by sampling the species from the seafloor and taking them into a 0.2 meter deep seawater basin where spectra were collected under sunlight. The in-lab scanning was performed on the same samples, temporarily stored in a marine sampling-grade cooler, and then placed under artificial halogen lighting in Petri dishes with a thin film of unfiltered seawater.

All spectral images were recorded using the ASD FieldSpec $\AA 3$ VNIR spectrometer (350$1050 \mathrm{~nm})$.

In order to gauge the variance of spectral signatures among closely related species, samples of C. racemosa from the Mediterranean were contrasted against a morphologically similar species, Caulerpa cf. laetevirens (Montagne 1842). C. cf. laetevirens can be found off the southeastern coast of USA (Florida) (LITTLER et al. 2008). In-lab spectral images were obtained for Caulerpa cf. laetevirens specimens that were collected in Fort Pierce, FL at depths from $10-15$ meters and transported to Grice Marine Laboratory, College of Charleston. The spectra were measured using the ASD FR Field Spectrometer in the full spectral range (350$2550 \mathrm{~nm}$ ) at the Department of Geology and Environmental Geosciences at the College of Charleston.

The numerical spectral reflectance values were transferred to a statistical package and the first derivative of the spectra was used to normalize the data.

\section{RESULTS}

Comparison of in-lab spectra of C. taxifolia and $C$. racemosa var. cylindracea indicated spectral regions of interest (Fig. 2). Both algae follow the expected similar pattern of reflectance peaks in green and near infrared spectral regions and absorption features in blue and red spectral regions, while Caulerpa taxifolia has a more pronounced absorption in the region of 900$950 \mathrm{~nm}$. The notable distinction between the two species is in the difference of the local absorption maximum for C. taxifolia at $670 \mathrm{~nm}$ and for C. racemosa var. cylindracea at $675 \mathrm{~nm}$.

The same difference can be observed in the spectral signatures taken in-air (Fig.3). In addition, in these signatures there is a notable difference in the reflection in the green region. All spectral curves of $C$. taxifolia had a local 


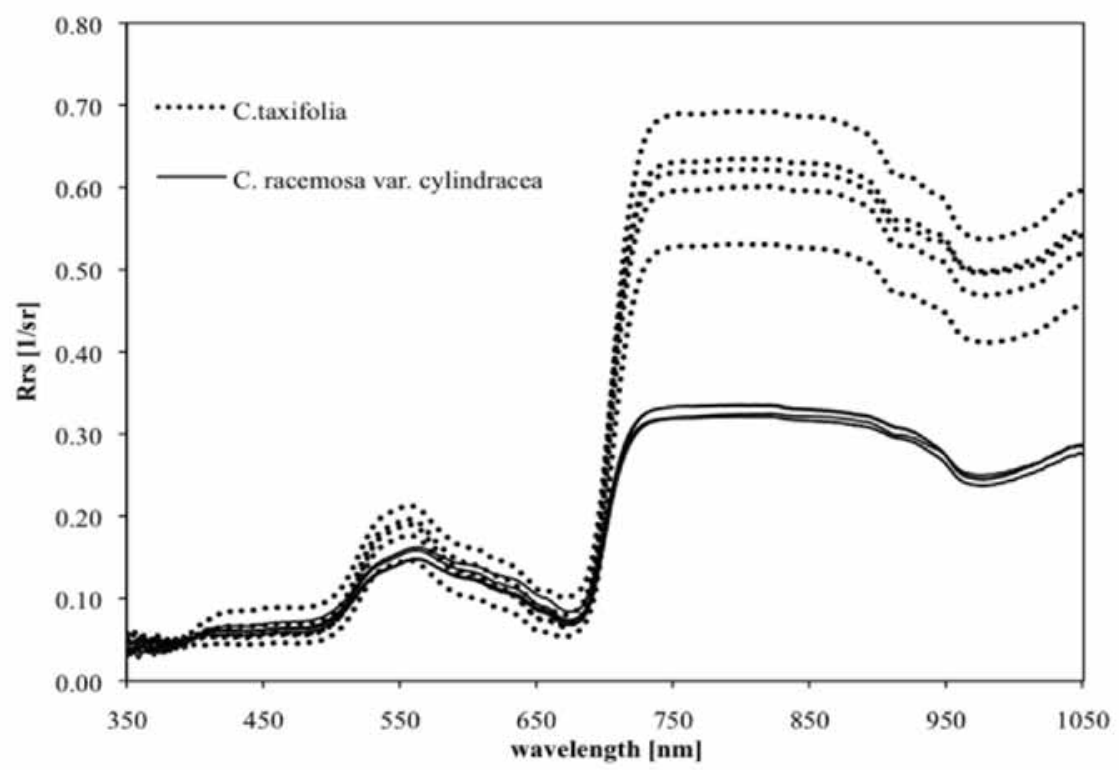

Fig.2. Comparison of in-lab reflectance spectra of C. racemosa var. cylindracea and C. taxifolia

reflection maximum at 557 or $558 \mathrm{~nm}$ while $C$. racemosa var. cylindracea had the maximum at $565 \mathrm{~nm}$. While most of the spectral differences between the two algae in the infrared region have been lost due to water absorption, there is an observable local reflection maximum for $C$. taxifolia at $761 \mathrm{~nm}$.

The spectral reflectance curve of $C$. $c f$. laetevirens natively found off the southeastern coast of the USA, revealed small differences in the position of an observed local reflection maximum at $568 \mathrm{~nm}$ and the local absorption maximum at $668 \mathrm{~nm}$ in comparison with $C$. racemosa var. cylindracea samples from the Adriatic Sea (Fig.4). There is also an observable difference in absorption features in the region of 530-560 nm.

The independent $t$-test showed that these observable differences are statistically significant $(p<0.05)$ between values of the first derivative at $530 \mathrm{~nm}(\mathrm{t}(8)=32.23, \mathrm{p}<0.05), 568$ $\mathrm{nm}(\mathrm{t}(8)=29.14, \mathrm{p}<0.05)$ and $668 \mathrm{~nm}(\mathrm{t}(8)=19.58$,

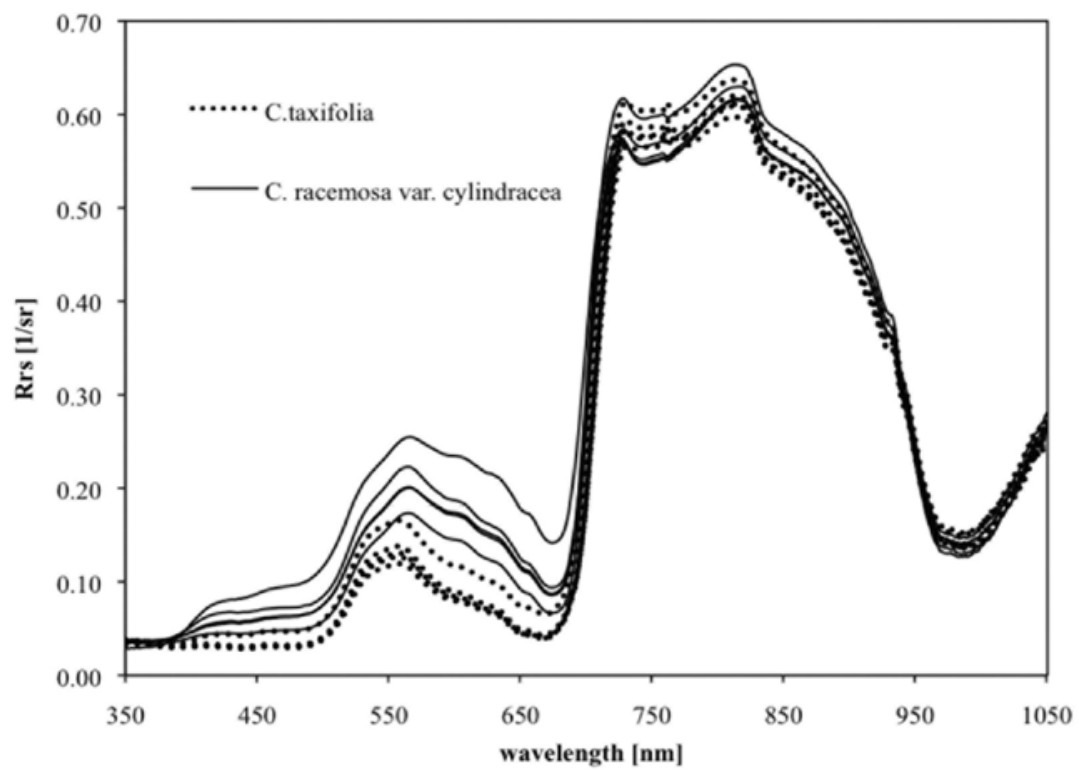

Fig. 3. Comparison of in-air reflectance spectra of C. racemosa var. cylindracea and C. taxifolia 


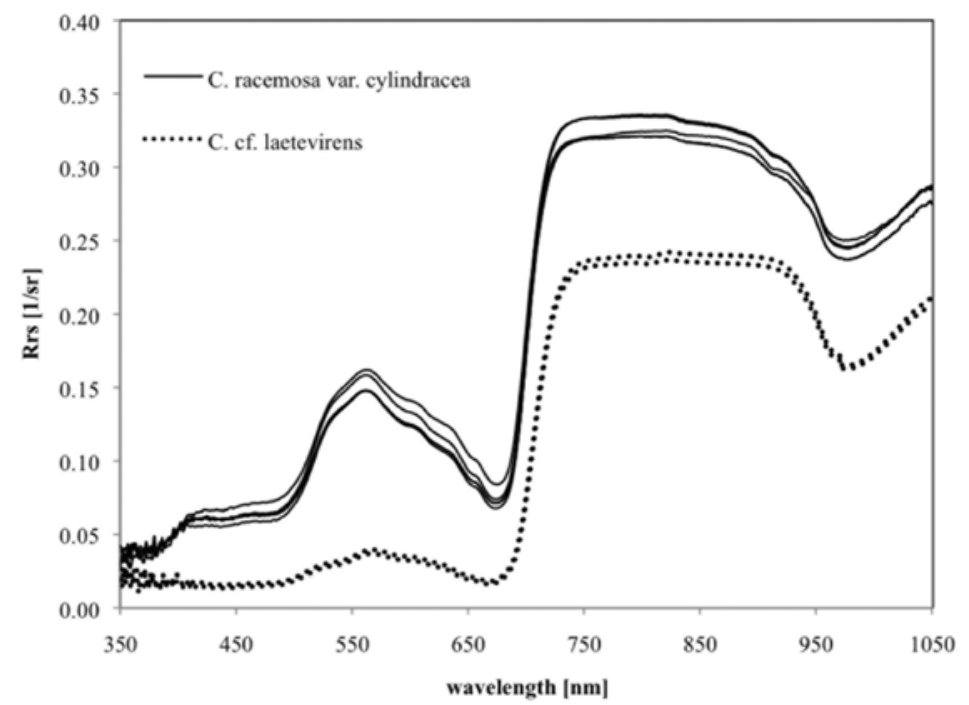

Fig.4.Comparison of in-lab reflectance spectra of C. racemosa var. cylindracea and C. cf. laetevirens

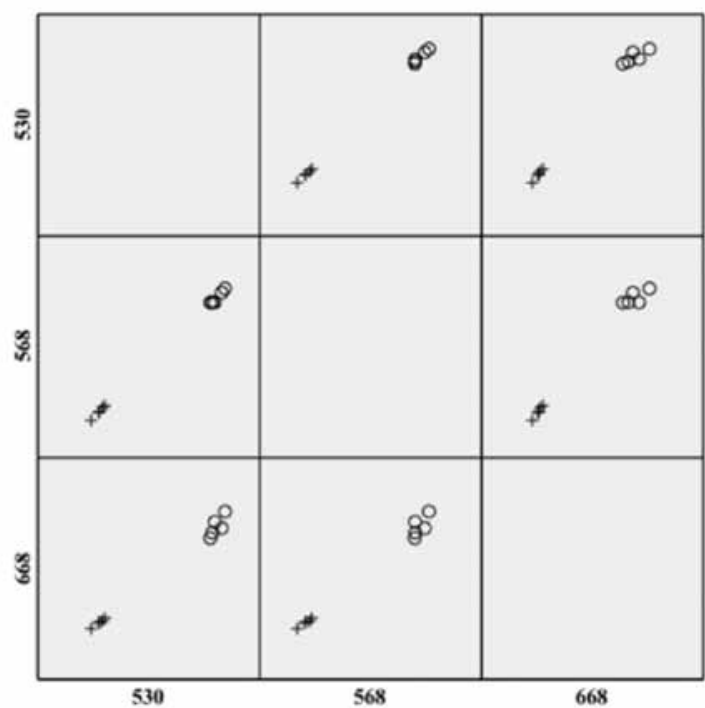

$$
\begin{gathered}
\text { Group } \\
01 \\
+2
\end{gathered}
$$

Fig.5. 2D scatter plot of the values of the first derivative of the C. racemosa var. cylindracea samples from the Adriatic Sea (Group 1) and C. cf. laetevirens samples from the USA (Group 2)

$\mathrm{p}<0.05)$ from the USA and the Adriatic Sea samples. This differentiation between two groups of samples can be observed by scatter plot (Fig.5).

\section{DISCUSSION}

The initial results indicate that it might be possible to distinguish between the observed Caulerpa species based on their spectral reflectance profiles. The statistical analysis showed a significant difference between the two groups of samples. To confirm this observation it would be necessary to collect samples from more populations and in different phenological phases of algae. The observed spectral differences could be a result of the spectral variability within each species and not a characteristic feature.

More extensive research is needed to characterize the spectral features of observed algae in-situ in relation to different microhabitat conditions and seasonal and daily changes in the light environment. Besides the effect of water attenuation, other properties that should be examined in relation to their effect on the spectral profile are depth changes of pigment 
composition and photosynthetic parameters. These changes are reportedly a widespread feature/occurrence in macroalgae (RAMUS et al. 1976). Some recent studies showed that Caulerpa racemosa var. cylindracea exhibits photoacclimation to depth and daily light cycle that is characterized by changes in levels of certain carotenoid pigments (RANIELLO et al. 2004, 2006).

Furthermore, to allow for the accurate remotely sensed mapping of the invasive caulerpas in the coastal zone of the Adriatic Sea, mixing properties with other benthic optical signals would need to be examined. It is particularly important to discriminate the spectral signal characteristics of Caulerpa from the signal and signature of Posidonia oceanica, since Caulerpa in the Adriatic Sea often competes for the available habitat with Poseidonia oceanica. Hence, it would be of paramount importance to delineate the spectral signatures of areal mixtures of the two species and the minimum detectability thresholds of either or both species within the larger frame. The invasive Caulerpa sp. in the Mediterranean Sea form continuous, dense meadows, while in south-western Australia where C. racemosa occurs natively, it is intermixed with other algae without forming monospecific meadows (CARRUTHERS et al. 1993, VERLAQUE et al. 2003). Such dense growth makes the invasive Caulerpa species more easily detectable on images with larger spatial scales.

\section{ACKNOWLEDGMENTS}

We are grateful to Alexandar Goetz Instrument Support Programe which provided us with the spectrometer that we used in the research. We are also very grateful to Dr. Ante ŽULJEVIĆ from the Institute of Oceanography and Fisheries in Split, Croatia, for location guidance, Dr. Fred MACKENZIE, University of Hawaii and the staff of the Grice Marine Laboratory, College of Charleston, for the collection of spectral samples of Caulerpa racemosa. We would also like to thank Ivana VUKOVIĆ and Dajana BRAJČIĆ for the field assistance.

\section{REFERENCES}

CARPENTER, R. 1986. Partitioning herbivory and its effects on coral reef algal communities. Ecol. Monogr., 56: 345-363.

CARRUTHERS, T.J. B., D. I. WALKER \& J.M.HUISMAN. 1993. Culture Studies on Two Morphological Types of Caulerpa (Chlorophyta) from Perth, Western Australia, with a Description of a New Species. Bot. Mar., 36: 589-596.

CECCHERELLI, G., D. CAMPO \& L. PIAZZI. 2001. Some ecological aspects of the introduced alga Caulerpa racemosa in the Mediterrannean: way of dispersal and impact on native species. Biol. Mar. Mediterr., 8: 94-99.

HAY, M. E. 1997. The ecology and evolution of seaweed-herbivore interactions on coral reefs. Coral Reefs, 16: S67-S76.

JOUSSON, O., J. PAWLOWSKI, L. ZANINETTI, F. W. ZECHMAN, F. DINI, G. DI GUISEPPE, R. WOODFIELD, A. MILLAR \& A. MEINESZ. 2000. Invasive alga reaches California. Nature, 408: 157-158.

KLEIN, J. \& M. VERLAQUE. 2008. The Caulerpa racemosa invasion: A critical review. Mar. Pollut. Bull., 56: 205-225.

LITTLER, D., M. LITTLER \& D. HANISAK. 2008. Submersed plants of the Indian River Lagoon. Off Shore Graphics, Inc., Washington, D.C., 1-2861.

MALTESE, A., V. PAMPALONE, T. J. MALTHUS, G. CIRAOLO, E. KARPOUZLI \& G. LA LOGGIA. 2008. Processing of field spectroradiometric data for remote sensing mapping of submerged vegetation in coastal zones and lagoon environments. EARSeL eProceedings, pp. 105-119.

MEINESZ, A., J. DE VAUGELAS, B. HESSE \& X. MARI. 1993. Spread of the introduced tropical green alga Caulerpa taxifolia in northern Mediterranean waters. J. Appl. Phycol., 5: 141-147.

NIZAMUDDIN, M. 1991. The Green Marine Algae of Libya. Elga Publisher (Bern).

PIAZZI, L., G. CECCHERELLI \& F. CINELLI. 2001. Threat to macroalgal diversity: effects of the introduced green alga Caulerpa racemosa in the Mediterranean Mar. Ecol. Prog. Ser., 210: 149-159. 
RAMUS, J., S. I. BEALE, D. MAUZERALL \& K. L. HOWARD. 1976. Changes in photosynthetic pigment concentration in seaweeds as a function of water depth. Mar. Biol., 37: 223229.

RANIELlO, R., M. LORENTI, C. BRUNET \& M. C. BUIA. 2004. Photosynthetic plasticity of an invasive variety of Caulerpa racemosa in a coastal Mediterranean area: light harvesting capacity and seasonal acclimation. Mar. Ecol. Prog. Ser., 271: 113-120.

RANIELlO, R., M. LORENTI, C. BRUNET \& M. C. BUIA. 2006. Photoacclimation of the invasive alga Caulerpa racemosa var. cylindracea to depth and daylight patterns and a putative new role for siphonaxanthin. Mar. Ecol., 27: 20-30.

SCHAFFELKE, B. \& C. L. HEWITT. 2007. Impacts of introduced seaweeds. Bot. Mar., 50: 397417.
SCHAFFELKE, B., N. MURPHY \& S. UTHICKE. 2002. Using genetic techniques to investigate the sources of the invasive alga Caulerpa taxifolia in three new locations in Australia. Mar. Pollut. Bull., 44: 204-210.

THOMSEN, M. S., T. WERNBERG, F. TUYA \& B. R. SILLIMAN. 2009. Evidence for impacts of nonindigenous macroalgae: a meta-analysis of experimental field studies. J. Phycol., 45: 812-819.

VERLAQUE, M., C. DURAND, J. M. HUISMAN, C.-F. BOUDOURESQUE \& Y. LE PARCO. 2003. On the identity and origin of the Mediterranean invasive Caulerpa racemosa (Caulerpales, Chlorophyta). Eur. J. Phycol., p. 38.

ŽULJEVIĆ, A., B. ANTOLIĆ \& V. ONOFRI. 2003. First record of Caulerpa racemosa (Caulerpales: Chlorophyta) in the Adriatic Sea. J. Mar. Biol. Assoc. U.K., 83: 711-712.

ŽULJEVIĆ, A., M. DESPALATOVIĆ \& V. NIKOLIĆ. 2010. http://jadran.izor.hr/kaulerpa/.

Received: 1 June 2010

Accepted: 22 February 2011 


\title{
Spektralni profili vrsta Caulerpa racemosa var. cylindracea i Caulerpa taxifolia u Jadranskom moru
}

\author{
Mak KIŠEVIĆ ${ }^{*}$, Amer SMAILBEGOVIĆ ${ }^{2}$, Kyle T. GRAY ${ }^{3}$, Roko ANDRIČEVIĆ ${ }^{1}$, Jonathan D. \\ CRAFT $^{4}$, Vedran PETROV ${ }^{1}$, Dajana BRAJČIĆ ${ }^{1}$ i Ivana DRAGIČEVIĆ ${ }^{1}$ \\ ${ }^{1}$ Fakultet Građevinarstva, arhitekture i geodezije, Sveučilište u Splitu, Hrvatska \\ ${ }^{2}$ Photon d.o.o., Split, Hrvatska \\ ${ }^{3}$ Odsjek za geologiju i geoznanosti, Veleučilište Charleston, SC, Sjedinjene Američke Države \\ ${ }^{4}$ Grice centar za istraživanje mora, Veleučilište Charleston, SC, Sjedinjene Američke Države
}

*Kontakt adresa, e-mail: mak.kisevic@gradst.hr

\begin{abstract}
SAŽETAK
Invazivne alge u Sredozemnom moru, Caulerpa taxifolia i Caulerpa racemosa var. cylindracea, su izazvale mnogo interesa zbog svojeg brzog širenja i negativnih utjecaja na nativne vrste morskog raslinja. Jednu od najvećih poteškoća za upravljanje ovim invazivnim vrstama predstavlja nedostatak preciznih karata rasprostranjenosti, odnosno visoka cijena izrade ovakvih karata. Tehnike daljinske detekcije mogu pružiti brži, učinkovitiji i ekonomičniji način kartiranja ovih vrsta. Kako bi omogućili klasifikaciju podataka prikupljenih daljinskom detekcijom, sakupljeni su i analizirani hiperspektralni profili obje invazivne vrste kaulerpe u Jadranu i nativne vrste Caulerpa cf. laetevirens na jugoistočnoj atlantskoj obali Sjedinjenih Američkih Država. Izmjerena su i utvrđena karakteristična spektralna obilježja ovih vrsta u cilju omogućavanja njihovog spektroskopskog razlikovanja, što je naročito interesantno u onim područjima gdje koegzistiraju nativne i invazivne vrste kaulerpe. Inicijalni rezultati pokazuju da je moguće razlikovati vrste između ovih tipova na osnovu njihovog spektralnog profila. Ovi rezultati još trebaju biti potvrđeni na uzorcima iz više populacija u različitim fenološkim fazama i u različitim uvjetima okoliša.
\end{abstract}

Ključne riječi: alge, optička svojstva, monitoring okoliša, daljinska detekcija 